\title{
EVALUATION OF ASSORTMENTS CONSIDERING DIFFERENT STUMP AND PRE-BUCKING DISC HEIGHTS IN MECHANIZED HARVESTING OPERATIONS OF A Pinus taeda L. FOREST
}

\author{
Gustavo Silva Oliveira ${ }^{{ }^{*}}$, Philipe Ricardo Casemiro Soares ${ }^{3}$, Jean Alberto Sampietro ${ }^{3}$, Maycon Thuan Saturnino \\ da Silva ${ }^{2}$, Marcos Filipe Nicoletti ${ }^{3}$, Julio Peretti da Silva ${ }^{3}$

\begin{abstract}
${ }^{1 *}$ Federal University of Paraná, Department of Rural Economy and Extension - DERE, Curitiba. Paraná, Brazil - gustavo_ccp@ hotmail.com ${ }^{2}$ Federal University of Paraná, Department of Forest Sciences - DECIF, Curitiba. Paraná, Brazil - (mayconthuan@ hotmail.com) ${ }^{3}$ University of the State of Santa Catarina, Department of Forest Engineering, Lages, Santa Catarina, Brasil - (philipe.soares@udesc.br;
\end{abstract} \\ jean.sampietro@udesc.br; marcos.nicoletti@udesc.br; icoperetti@hotmail.com)
}

Received for publication on: 25/09/2018 - Accepted for publication on: 11/03/2019

\begin{abstract}
Resumo
Avaliação de sortimentos adotando distintas alturas de toco e pré-traçamento na colheita florestal de Pinus taeda $L$. Este estudo buscou avaliar sortimentos, adotando distintas alturas de toco e pré-traçamento na colheita florestal mecanizada de Pinus taeda L., em uma empresa localizada no município de Campo Belo do Sul (SC). Assim, realizou-se a simulação de seis cenários nas intervenções de corte raso. O primeiro cenário seguiu as especificações da empresa, o segundo a situação real, por meio da mensuração realizada em unidades amostrais, no terceiro considerou-se altura de toco de $10 \mathrm{~cm}$ e pré-traçamento de $5 \mathrm{~cm}$ e, nos demais cenários, adotou-se alturas de toco e pré-traçamento superiores ao especificado pela empresa. Posteriormente, utilizando-se de uma função de afilamento, foram obtidas as estimativas de sortimentos em toneladas por hectare (t ha-1) e valor monetário por hectare ( $\mathrm{R} \$$ ha-1), considerando o preço madeira $\mathrm{c} /$ casca $(\mathrm{R} \$ \mathrm{t}-1)$ para cada sortimento. $\mathrm{O}$ Cenário 1, apresentou uma maior quantidade de madeira, no entanto, o Cenário 3 representou uma maior receita, devido a uma maior quantidade de madeira nos sortimentos com valor agregado. O Cenário 6 apresentou a menor quantidade de madeira em comparação aos demais e o Cenário 2 apresentou o menor retorno econômico. Dessa forma, a empresa realiza suas atividades abaixo do planejado, muito embora, com uma produção superior à dos demais cenários avaliados. Já em relação ao retorno econômico, os demais cenários são mais viáveis que o Cenário 2, evidenciando a necessidade em buscar melhorias do processo com a implantação de outro cenário, que possibilite melhores resultados.

Palavras-chave: Setor Florestal, função de afilamento, quantificação.
\end{abstract}

\begin{abstract}
This study aimed to evaluate assortments by adopting distinct stump heights and pre-bucking disc heights in the mechanized harvesting operations of a Pinus taeda L. forest, which is owned by a company located in Campo Belo do Sul (SC). To that end, the simulation of six scenarios was carried out after the forest's clearcutting. The scenario 1 includes the company's specifications. Scenario 2 includes the real situation, that is, the measurements made in sample units installed on the field and scenario 3 includes stump heights of $10 \mathrm{~cm}$ and pre-bucking disc heights of $5 \mathrm{~cm}$. In the other scenarios, stump and pre-bucking disc heights with values higher than the ones specified by the company were included. Then, using a taper function, we calculated the assortments in tons per hectare (t ha-1) and monetary value per hectare ( $\$$ ha-1), considering the price of wood with bark (R \$ t-1) for each assortment. Results show that Scenario 1 presented a larger amount of wood, however, Scenario 3 represented higher revenue due to the higher wood quantity of the value-added assortments. On the other hand, Scenario 6 presented the lowest amount of wood comparing to the others, and Scenario 2 presented the lowest economic return. All things considered, the company performs its activities below what is planned, but with production higher than the other evaluated scenarios. Regarding the economic return, the other scenarios are more feasible than Scenario 2, which shows that the company needs to seek process improvements with the implementation of another scenario that could bring better results. Keywords: Forest Sector, taper function, quantification.
\end{abstract}

\section{INTRODUCTION}

Growing development and increasing market demand for timber products influence forest-based organizations to expand their wood application possibilities and diversify their production. Currently, the sector encompasses a wide range of companies, investors, and entrepreneurs, ranging from the input supply to the final

FLORESTA, Curitiba, PR, v. 50, n. 1, p. 1133 - 1142, jan/mar 2020.

Oliveira, G. S. et.al.

ISSN eletrônico 1982-4688

DOI: $10.5380 /$ rf.v50 i1.61775 
product. They produce wood for multiple uses such as pulp, paper, panels, laminate floors, plywood panels, furniture, charcoal, biomass for energy purposes, among others (BRAZILIAN TREE INDUSTRY - IBÁ, 2016). Among the species used in Brazil, we highlight those of the genus Pinus, from which the Pinus taeda L. had its forestry intensified through tax incentives, promoted by the federal government.

However, there is still a need for researches that help and collaborate with the optimization of forest activities, mainly harvesting and forest transportation, which are the most economically relevant stages due to their significant contribution to the product's final cost and the loss threats attributed to operations (TRINDADE et al., 2012). According to Machado et al. (2008), forest harvesting represents nearly $50 \%$ of the final cost of the wood inserted in the factory.

Given the above, when seeking cost mitigation, it is fundamental to understand the production potential, the variables that affect yield, and the pursuit of techniques that optimize the operational performance of harvesting systems. Among the non-compliance factors in the forest harvesting process, we highlight the excess stump and pre-bucking disc heights in forest stands.

To better use forest raw materials, companies use assortments to meet their demands. The assortments allow the wood's multiple uses for different purposes, according to the diameter and length dimensions. Thus, to quantify forest stand assortments, taper functions are efficient alternatives because they allow estimating the total or commercial volume of the log at any specified diameter or height (MIGUEL et al., 2011).

Among the taper functions, polynomials of higher degrees allow the quantification of the area near the base of the trunk, as well as being a powerful instrument to economically evaluate forest (FONWEBAN et al., 2011). Therefore, among the many models established in the literature, the fifth-degree polynomial is widely used to estimate the volume of $\log$ s based on taper functions. Amidst the researches that used this method we have: Yoshitani Junior et al. (2012), Souza et al. (2008), Campos et al. (2013), Kohler et al. (2013), and Figueiredo Filho et al. (2015). Moreover, this technique contributes to the study of wood assortments that aim at higher productivity, efficiency, and quality in mechanized forest harvesting activities.

Therefore, this study aimed to evaluate assortments by adopting different stump and pre-bucking disc heights in mechanized forest operations of a Pinus taeda L. forest located at a company in Campo Belo do Sul, Santa Catarina, Brazil.

\section{MATERIALS AND METHODS}

\section{Study area}

The research has been carried out in areas of a forest company located in Campo Belo do Sul, Santa Catarina, Brazil. The area's predominant soil is the Hapludox, the average altitude is 950m, and the annual precipitation ranges from 1.300 to $2.400 \mathrm{~mm}$. The company performs around four to six thinning operations before the clear-cutting, according to the forest's development. Therefore, this study aimed to evaluate the stands after the clear-cutting. Table 1 describes the characteristics of the stands allocated for clear-cutting.

Table 1. Characteristics of stands allocated for the clear-cutting.

Tabela 2. Características dos povoamentos destinados ao corte raso.

\begin{tabular}{lc}
\hline \multicolumn{1}{c}{ Characteristics } & Clear-cutting \\
\hline Species & Pinus taeda \\
Stand's age (years) & 34 \\
Total area (ha) & 174.5 \\
Planting distance $(\mathrm{m})$ & $2.0 \times 3.0$ \\
Diameter at breast height $(\mathrm{cm})$ & 45.8 \\
Average height $(\mathrm{m})$ & 34.8 \\
Individual average volume $\left(\mathrm{m}^{3}\right)$ & 2.5 \\
Expected production $\left(\mathrm{m}^{3} / \mathrm{ha}\right)$ & 582.3 \\
Declivity $\left({ }^{\circ}\right)$ & $5-10 / 10-15$ \\
Declivity withdrawal $(\mathrm{N} / \mathrm{ha})$ & 233 \\
\hline Source: Adapted by the author from the Forest Company (2018).
\end{tabular}

FLORESTA, Curitiba, PR, v. 50, n. 1, p. 1133-1142, jan/mar 2020 


\section{Characterization of the mechanized forest harvesting operations}

The study has been conducted in a mechanized harvesting module in the cut-to-length log system. The machines used in the operations were Harvesters, Forwarders, and Loaders. First, the Harvesters were used for felling, debarking, bucking and yarding, that is, they felled the trees and made the logs available for extraction. Then the Forwarders carried out the extraction, which consists of carrying the felled logs from the stand to a roadside landing. Finally, hydraulic Loaders were used to load the logs into transport vehicles.

Aiming at achieving an effective quality control, the company presents in its planning the specifications for the several forest harvesting operations. The Harvesters are allowed to work with stump and pre-bucking disc heights of up to $15 \mathrm{~cm}$ and $10 \mathrm{~cm}$, respectively. The height of the stumps is limited to preserve and protect the harvester's head. Therefore, stump heights that surpass the company`s specifications entail losses, mainly because logs of higher added value are involved. The pre-bucking disc is the wooden disc that is chopped from the first log of the trunk by the harvesters. This procedure is performed as a safety measure when a forest presents large dimension trees as a way to contribute for a better bucking and to avoid damaging the logs.

\section{Classification of the assortments}

There are a variety of uses for the wood coming from the company's production. In this study, we analyzed the assortments that, according to the company's classification, are classified as logs without knots, "LP" (Pinus veneer) and "MPP" (Pinus for wood process). Table 2 shows the price of wood with bark sold by the company, valid from April 2017, and its possible purposes.

Table 2. Classification of the multiple uses of the wood from the company's Pinus spp. forests. Tabela 2. Classificação dos múltiplos usos oriundos das florestas de Pinus spp.

\begin{tabular}{|c|c|c|c|c|c|}
\hline \multirow{2}{*}{ Assortment } & \multicolumn{2}{|c|}{ Diameter $(\mathrm{cm})$} & \multirow{2}{*}{ Length (m) } & \multirow{2}{*}{$\begin{array}{c}\text { Price of wood } \\
\text { with bark }(R \$ t)\end{array}$} & \multirow{2}{*}{ Possible use } \\
\hline & Lowest & Highest & & & \\
\hline MPP & 8 & 18 & 2.7 & 40.00 & Energy \\
\hline LP01 & 18 & 25 & 2.7 & 119.00 & Cellulose \\
\hline LP02 & 25 & 35 & 2.7 & 197.00 & Sawn wood \\
\hline LP04 & 35 & 41.9 & 2.7 & 270.00 & Veneer wood \\
\hline LP06 & Over 42 & - & 2.7 & 352.00 & Veneer wood \\
\hline
\end{tabular}

\section{Simulation of scenarios}

To assess the effects of the mechanized harvesting process considering the different stump and prebucking disc heights, the number of logs and assortments obtained along the trunk in the clear-cutting operations were simulated, as shown in Table 3.

Table 3. Stump and pre-bucking disc heights $(\mathrm{cm})$ considering different scenarios in the clear-cutting operations. Tabela 3. Alturas de toco e pré-traçamento $(\mathrm{cm})$ para diferentes cenários em operações de corte raso.

\begin{tabular}{ccc}
\hline \multirow{2}{*}{ Scenarios } & \multicolumn{2}{c}{ Height $(\mathbf{c m})$} \\
\cline { 2 - 3 } & Stump & Pre-bucking \\
\hline 1 & 15.0 & 10.0 \\
2 & Real & Real \\
3 & 10.0 & 5.0 \\
4 & 20.0 & 15.0 \\
5 & 25.0 & 20.0 \\
6 & 35.0 & 20.0 \\
\hline
\end{tabular}

The characteristics of Scenario 1 (S1) were verified according to the company's specifications (stump and pre-bucking disc heights defined in the planning phase). For data collection in a real situation, Scenario 2 (S2), 
a pilot sampling with 10 sample units was performed by using the fixed area method and the random sampling process, with an area of $400 \mathrm{~m}^{2}$ and a quadrangular shape $(20 \mathrm{~m} \times 20 \mathrm{~m})$.

In this way, the diameter and the height of the stumps were collected in two positions and the diameter and the height of the pre-bucking discs that were found in the sampling units were measured with a tape measure. After that, mean values were determined for each variable. Later, the final number of samples for each intervention was given by the Equation 1(for an infinite population), in function of the total volume of the stumps and the prebucking discs $\left(\mathrm{m}^{3}\right)$. Afterward, the descriptive statistics were used to analyze the data to add and contribute to the interpretation of the results.

$$
n=\frac{t^{2} * C V \%^{2}}{E^{2}}
$$

in which: $n$ is the number of necessary samples, $t$ is the $t$ distribution value for a significance level at $95 \%, C V \%$ is the coefficient of variation (\%) and $E \%$ is the maximum error allowed (10\%).

In Scenario 3 (S3), we considered stump heights of $10.0 \mathrm{~cm}$ and pre-bucking disc heights of $5.0 \mathrm{~cm}$. In the other scenarios, S4, S5, and S6, we adopted stump and pre-bucking disc heights higher than the ones specified by the company, allowing a $10.0 \mathrm{~cm}$ interval from one scenario to another. As the company specified stump and prebucking heights of $25.0 \mathrm{~cm}$, we sought heights below $15.0 \mathrm{~cm}$ for the S3 and, for scenarios S4, S5 and S6, we considered $35.0,45.0$, and $55.0 \mathrm{~cm}$, respectively.

Afterward, we obtained the estimation of the assortments in tons per hectare $\left(\mathrm{t} \mathrm{ha}^{-1}\right)$ and monetary value per hectare $\left(\mathrm{R} \$ \mathrm{ha}^{-1}\right)$, considering the price of wood with bark $\left(\mathrm{R} \$ \mathrm{t}^{-1}\right)$ for each assortment.

\section{Estimation of the assortments}

The assortments were evaluated in different scenarios by using the Schöepfer's taper function, which allowed us to obtain the diameters at different heights and the total and partial volumes of the tree stems. Thus, through the company's inventory of timber stock, we created a frequency distribution table (FDT) adopting the diameter at breast height $(\mathrm{DBH})$ of the individuals allocated for clear-cutting. The data were gathered into classes, considering the Sturges's statistical method and using the descriptive statistics to obtain the following variables: number of classes, amplitude, lower limit (LL), upper limit (UP), midpoint (Xi), absolute frequency (AF), and relative frequency $(\mathrm{RF})$.

To that end, from the total trees obtained from the forest inventory of wood stock we selected a tree with DBH compatible with each diameter class and, afterward, we measured its DBH $(\mathrm{cm})$ and total height $(\mathrm{m})$ to make the estimates.

To obtain the diameter at any specific heights, it is necessary to isolate the di variable from the diameter at breast height (DBH) and the total height (h) values in the Schöepfer's function (SCHÖEPFER, 1966), as shown in Equation (2).

$$
\frac{d i}{D A P}=\beta_{0}+\beta_{1}\left(\frac{h i}{h}\right)+\beta_{2}\left(\frac{h i}{h}\right)^{2}+\beta_{3}\left(\frac{h i}{h}\right)^{3}+\beta_{4}\left(\frac{h i}{h}\right)^{4}+\beta_{5}\left(\frac{h i}{h}\right)^{5}+\varepsilon_{i}
$$

in which: $d i$ is the estimated diameter $(\mathrm{cm}), h i$ is the height along the trunk $(\mathrm{m}), \mathrm{DBH}$ is the diameter at breast height $(\mathrm{cm}), h$ is the total height $(\mathrm{m}), \beta 0, \beta 1, \beta 2, \beta 3, \beta 4$, and $\beta 5$ are the equation parameters to be estimated, and $\varepsilon i$ is the error of estimate.

By isolating $d i$ we can obtain the taper function that can estimate the diameter at any tree height (Equation

$$
d i=\operatorname{dap}\left(\beta_{0}+\beta_{1} \frac{h i}{h}+\beta_{2}\left(\frac{h i}{h}\right)^{2}+\beta_{3}\left(\frac{h i}{h}\right)^{3}+\beta_{4}\left(\frac{h i}{h}\right)^{4}+\beta_{5}\left(\frac{h i}{h}\right)^{5}\right)
$$

To integrate the function and get to the equation that allows the estimation of the volumes, we made the following simplification.

$$
c_{0}=\beta_{0} ; c_{1}=\frac{\beta_{1}}{h^{1}} ; c_{2}=\frac{\beta_{2}}{h^{2}} ; \ldots ; c_{5}=\frac{\beta_{5}}{h^{5}}
$$

Afterward, we integrated the function of the sectional area between the desired upper (h2) and lower (h1) limits to obtain the volume over bark (v) as presented in Equations 4 and 5.

FLORESTA, Curitiba, PR, v. 50, n. 1, p. 1133-1142, jan/mar 2020 


$$
\begin{gathered}
v=K \int_{h 1}^{h 2} d i^{2} \delta h \\
v=K D A P^{2} \int_{h 1}^{h 2}\left(c_{0}+c_{1} h_{i}+c_{2} h_{i}^{2}+\ldots+c_{5} h_{i}^{5}\right)^{2} \delta h
\end{gathered}
$$

The Equation 6 is the result of the integration of Equation 5. It allows to obtain the commercial assortments and volumes that correspond to any portion of the tree and/or the total volume.

$$
\begin{aligned}
& v=K * D A P^{2}\left[\frac{1}{11} c_{5}^{2} h_{i}^{11}+\frac{1}{5} c_{4} c_{5} h_{i}^{10}+\frac{1}{9}\left(2 c_{5} c_{3}+c_{4}^{2}\right) h_{i}^{9}+\frac{1}{8}\left(2 c_{3} c_{4}+2 c_{5} c_{2}\right) h_{i}^{8}+\frac{1}{7}\left(2 c_{2} c_{4}+2 c_{5} c_{1}+c_{3}^{2}\right) h_{i}^{7}+\right. \\
& \frac{1}{6}\left(2 c_{1} c_{4}+2 c_{3} c_{2}+2 c_{5} c_{0}\right) h_{i}^{6}+\frac{1}{5}\left(c_{2}^{2}+2 c_{4} c+2 c_{1} c\right) h_{i}^{5}+\frac{1}{4}\left(2 c_{3} c_{0}+2 c_{1} c_{2}\right) h_{i}^{4}+\frac{1}{3}\left(c_{1}^{2}+2 c_{2} c_{0}\right) h_{i}^{3}+c_{0} c_{1} h_{i}^{2}+ \\
& \left.c_{0}^{2} h_{i}\right]_{h 1}^{h 2}
\end{aligned}
$$

in which: $v$ is the assortment's volume $\left(\mathrm{m}^{3}\right), K$ is $\pi / 40000, \mathrm{DBH}$ is the diameter at breast height (cm), and $h i$ is the height along the trunk $(\mathrm{m})$.

After the quantification of the assortments, the volumes were transformed into mass and quantified, because the final product is marketed in tons. To that end, the conversion factor 0.828 was used for the Pinus with bark. In addition to the quantification of the logs, the estimation of the assortments was obtained in tons per hectare $\left(\mathrm{t} \mathrm{ha}^{-1}\right)$ and monetary value per hectare $\left(\mathrm{R} \$ \mathrm{ha}^{-1}\right)$.

The Schöepfer's model (Fifth Degree Polynomial - 1966) is used by the company and, therefore, the information needed for the evaluation of the statistical adjustment and accuracy were provided by the company, in accordance with the parameters described by Draper and Smith (1966): Graphical residual analysis (\%), Adjusted coefficient of determination ( $\mathrm{R}^{2} \mathrm{aj}$ ), and Standard error of estimate in percentage (Syx\%). The statistical parameters of the fifth degree polynomial of the variable di (diameter over bark), in centimeters, with the adjusted coefficient of determination ( $\mathrm{R}^{2} \mathrm{aj}$ ) and the standard error of estimate (Syx\%), in percentage, that were provided by the company are presented in Table 4 .

Table 4. Statistical parameters and coefficients of the adjusted taper function for the variable $\mathrm{di}$.

Tabela 4. Coeficientes e parâmetros estatísticos para a equação de afilamento ajustada para variável di.

\begin{tabular}{lccccccccc}
\hline \multirow{2}{*}{ Species } & \multirow{2}{*}{ Author } & \multicolumn{1}{c}{ Coefficients } & \multirow{2}{*}{$\mathbf{R}^{2} \mathbf{a j}$} & $\mathbf{S}_{\mathbf{y x}} \boldsymbol{\%}$ \\
\cline { 3 - 10 } & & $\boldsymbol{\beta}_{\mathbf{0}}$ & $\boldsymbol{\beta}_{\mathbf{1}}$ & $\boldsymbol{\beta}_{\mathbf{2}}$ & $\boldsymbol{\beta}_{\mathbf{3}}$ & $\boldsymbol{\beta}_{\mathbf{4}}$ & $\boldsymbol{\beta}_{\mathbf{5}}$ & & \\
\hline Pinus taeda & Schöepfer & 1.08 & 3.15 & 13.42 & 27.96 & 25.43 & 8.82 & 0.97 & 6.41 \\
\hline Source: Forest Company. & & & & & & & &
\end{tabular}

\section{RESULTS}

The summary of the descriptive statistics of the volume data $\left(\mathrm{m}^{3}\right)$ of the experimental plots considering the stump and pre-bucking disc heights obtained from the clear-cutting operation are presented in Table 5.

Table 5. Descriptive statistics of the volume data $\left(\mathrm{m}^{3}\right)$ of the experimental plots considering the stump and prebucking disc heights in the clear-cutting operation.

Tabela 53. Informações estatísticas dos dados de volume $\left(\mathrm{m}^{3}\right)$ das parcelas para toco e pré-traçamento no corte raso.

\begin{tabular}{lcc}
\hline \multirow{2}{*}{ Volume $\left(\mathrm{m}^{3}\right)$} & \multicolumn{2}{c}{ Clear-cutting } \\
\cline { 2 - 3 } & Stump & Pre-bucking \\
\hline Minimum $\left(\mathrm{m}^{3}\right)$ & 0.00610 & 0.00300 \\
Mean $\left(\mathrm{m}^{3}\right)$ & 0.00739 & 0.00357 \\
Maximum $\left(\mathrm{m}^{3}\right)$ & 0.00868 & 0.00475 \\
Standard deviation $\left(\mathrm{m}^{3}\right)$ & 0.00092 & 0.00068 \\
Coefficient of variation $(\%)$ & 12,47 & 19.13 \\
Standard error of the estimate $\left(\mathrm{m}^{3}\right)$ & 0.00029 & 0.00027
\end{tabular}

FLORESTA, Curitiba, PR, v. 50, n. 1, p. 1133 - 1142, jan/mar 2020.

Oliveira, G. S. et.al.

ISSN eletrônico 1982-4688 
A total of 21 experimental plots were applied in the clear-cutting by calculating the necessary sample intensity with the application of the 10 sample units. This has shown that the study was satisfactory in estimating the volume in scenario $2(\mathrm{~S} 2)$.

\section{Quantification of the assortments} in Table 6.

The descriptive statistics of the clear-cutting forest interventions as a function of the DBH are presented

Table 6. Statistical information of the DBH data $(\mathrm{cm})$ of the trees intended for the clear-cutting interventions. Tabela 6. Informações estatísticas dos dados de DAP $(\mathrm{cm})$ dos indivíduos destinados as intervenções de corte raso.

\begin{tabular}{lc}
\hline \multicolumn{1}{c}{ Statistics } & DBH $(\mathbf{c m})$ \\
\hline Minimum $(\mathrm{cm})$ & 25.0 \\
Mean $(\mathrm{cm})$ & 44.9 \\
Maximum $(\mathrm{cm})$ & 65.0 \\
Standard deviation $(\mathrm{cm})$ & 7.2 \\
Coefficient of variation $(\%)$ & 16.0 \\
Sampling error & 0.52 \\
\hline
\end{tabular}

Table 7 presents the lower limit, the midpoint and the upper limit of each diametric class, the absolute frequency (N/ha), the stump and pre-bucking disc heights of scenario $2(\mathrm{~S} 2)$, and the DBH (cm) and total height $(\mathrm{m})$ of the trees selected from the forest inventory of wood stock of each diametric class.

Table 7. Lower limit, midpoint and upper limit of each diametric class, absolute frequency (N/ha), stump and prebucking disc heights of Scenario 2, and DBH $(\mathrm{cm})$ and total height $(\mathrm{m})$ of the trees chosen from the forest inventory of wood for each diametric class.

Tabela 7. Limite inferior, ponto médio e limite superior de cada classe diamétrica, frequência absoluta (N/ha), altura de toco e pré-traçamento do Cenário 2 e características dendrométricas de DAP $(\mathrm{cm})$ e altura total (m) dos indivíduos selecionados do inventário florestal de estoque de madeira para cada classe.

\begin{tabular}{|c|c|c|c|c|c|c|c|c|}
\hline \multirow{3}{*}{ Classes } & \multirow{3}{*}{$\begin{array}{c}\text { Lower } \\
\text { limit } \\
(\mathrm{cm})\end{array}$} & \multirow{3}{*}{$\begin{array}{l}\text { Midpoint } \\
\text { (cm) }\end{array}$} & \multirow{3}{*}{$\begin{array}{c}\text { Upper } \\
\text { limit } \\
(\mathbf{c m})\end{array}$} & \multirow{3}{*}{$\begin{array}{l}\text { Absolute } \\
\text { frequency } \\
\text { (N/ha) }\end{array}$} & \multirow{2}{*}{\multicolumn{2}{|c|}{ Tree heights of S2 (cm) }} & \multicolumn{2}{|c|}{ Trees } \\
\hline & & & & & & & \multirow{2}{*}{$\begin{array}{r}\text { DBH } \\
(\mathbf{c m})\end{array}$} & \multirow{2}{*}{$\begin{array}{c}\text { Total } \\
\text { height } \\
\text { (m) }\end{array}$} \\
\hline & & & & & Stump & Pre-bucking & & \\
\hline 1 & 22.3 & 25.0 & 27.7 & 4 & 15.5 & 32.0 & 25.0 & 29.2 \\
\hline 2 & 27.8 & 30.0 & 33.1 & 5 & 30.0 & 31.5 & 33.0 & 35.4 \\
\hline 3 & 33.2 & 36.0 & 38.5 & 33 & 8.0 & 7.1 & 36.0 & 34.0 \\
\hline 4 & 38.6 & 41.0 & 43.9 & 64 & 25.3 & 12.2 & 42.0 & 33.5 \\
\hline 5 & 44.0 & 47.0 & 49.3 & 67 & 23.9 & 13.8 & 46.0 & 33.8 \\
\hline 6 & 49.4 & 52.0 & 54.8 & 36 & 24.2 & 10.9 & 52.0 & 35.6 \\
\hline 7 & 54.9 & 58.0 & 60.2 & 17 & 23.6 & 10.4 & 58.0 & 32.3 \\
\hline 8 & 60.3 & 63.0 & 65.6 & 7 & 23.9 & 12.2 & 62.0 & 27.3 \\
\hline
\end{tabular}

After the selection of the trees for each diametric class, the different scenarios were compared for the five assortments found in the clear-cutting operation (Figure 1). 


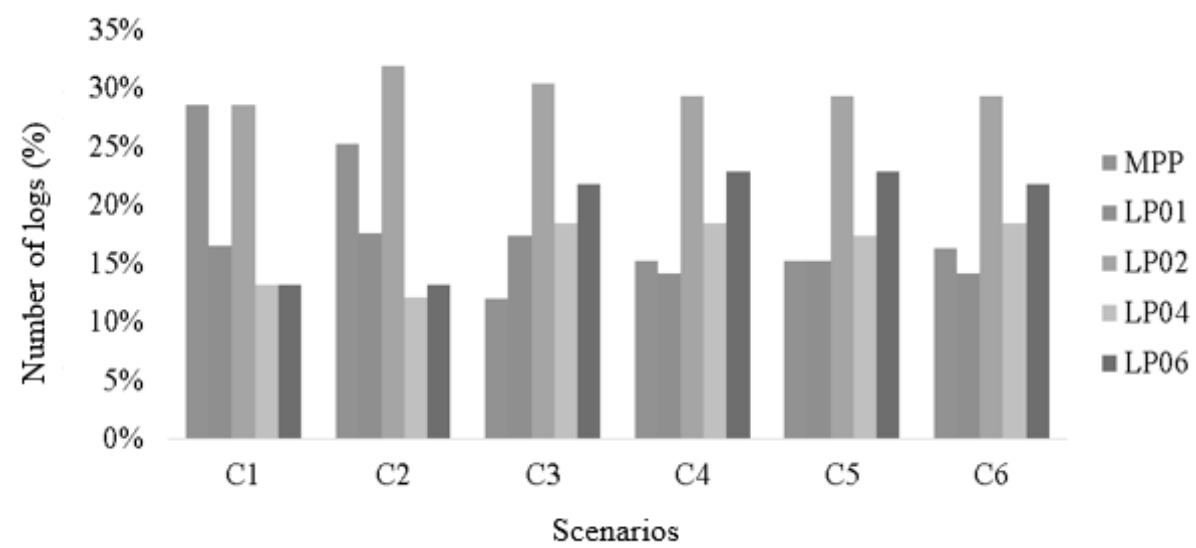

Figure 1. Amount of $\operatorname{logs}(\%)$ for the different assortments in each scenario. LP: Pinus veneer; MPP: Pinus for wood process.

Figura 1. Quantidade de toras (\%) por hectare (ha) para os diferentes sortimentos em cada cenário. LP: lâmina de pinus; MPP: madeira para processo de pinus.

Table 8 presents the quantification of the assortments in tons per hectare $\left(\mathrm{t} \mathrm{ha}^{-1}\right)$ and monetary value per hectare $\left(\mathrm{R} \$ \mathrm{ha}^{-1}\right)$ for each assortment in the different evaluated scenarios.

Table 8. Quantification of assortments in tons per hectare $\left(\mathrm{t} \mathrm{ha}^{-1}\right)$ and monetary value per hectare $\left(\mathrm{R} \$ \mathrm{ha}^{-1}\right)$ for each assortment in the different evaluated scenarios. LP: Pinus veneer; MPP: Pinus for wood process.

Tabela 8. Quantificação dos sortimentos em toneladas por hectare $\left(\mathrm{t} \mathrm{ha}^{-1}\right)$ e valor monetário por hectare $\left(\mathrm{R} \$ \mathrm{ha}^{-1}\right)$ para cada sortimento nos diferentes cenários avaliados. LP: lâmina de pinus; MPP: madeira para processo de pinus.

\begin{tabular}{|c|c|c|c|c|c|c|c|}
\hline Scenario & Assortment & t ha ${ }^{-1}$ & $\mathbf{R} \$ \mathbf{h a}^{-1}$ & Scenario & Assortment & t hat ${ }^{-1}$ & $\mathbf{R} \$ \mathbf{h a}^{-1}$ \\
\hline \multirow{6}{*}{1} & MPP & 30.65 & $1,226.02$ & \multirow{6}{*}{4} & MPP & 6.24 & 249.74 \\
\hline & LP01 & 48.68 & $5,792.69$ & & LP01 & 22.00 & $2,617.79$ \\
\hline & LP02 & 153.20 & $30,179.91$ & & LP02 & 96.94 & $19,097.17$ \\
\hline & LP04 & 118.35 & $31,955.37$ & & LP04 & 108.98 & $29,425.59$ \\
\hline & LP06 & 181.55 & $63,906.95$ & & LP06 & 236.80 & $83,353.89$ \\
\hline & Total & 532.43 & $133,060.93$ & & Total & 470.97 & $134,744.19$ \\
\hline \multirow{6}{*}{2} & MPP & 23.28 & 931.34 & \multirow{6}{*}{5} & MPP & 6.03 & 241.38 \\
\hline & LP01 & 47.35 & $5,634.77$ & & LP01 & 23.01 & $2,738.09$ \\
\hline & LP02 & 160.48 & $31,614.80$ & & LP02 & 98.17 & $19,340.21$ \\
\hline & LP04 & 108.41 & $29,269.94$ & & LP04 & 101.79 & $27,482.68$ \\
\hline & LP06 & 166.65 & $58,661.08$ & & LP06 & 237.77 & $83,696.51$ \\
\hline & Total & 506.17 & $126,111.93$ & & Total & 466.78 & $133,498.88$ \\
\hline \multirow{6}{*}{3} & MPP & 4.15 & 165.82 & \multirow{6}{*}{6} & MPP & 5.96 & 238.26 \\
\hline & LP01 & 25.05 & $2,981.31$ & & LP01 & 22.58 & $2,687.31$ \\
\hline & LP02 & 106.28 & $20,936.36$ & & LP02 & 97.30 & $19,168.29$ \\
\hline & LP04 & 114.92 & $31,029.16$ & & LP04 & 109.96 & $29,689.15$ \\
\hline & LP06 & 229.17 & $80,668.68$ & & LP06 & 226.87 & $79,857.00$ \\
\hline & Total & 479.57 & $135,781.32$ & & Total & 462.67 & $131,640.00$ \\
\hline
\end{tabular}

FLORESTA, Curitiba, PR, v. 50, n. 1, p. 1133 - 1142, jan/mar 2020. 


\section{DISCUSSION}

There is a relationship between the classes' midpoint and frequency (Table 7), presenting a higher concentration of trees in the classes of the diameter distribution center, which characterizes the planted forests like the ones of the Pinus genus. These results are similar to the ones found by Téo et al. (2011), who studied the diameter distribution of Pinus taeda L stands in the region of Caçador (SC), and by Binoti et al. (2010), who studied stands ten years after the thinning operations of a Eucalyptus grandis $\mathrm{x}$ Eucalyptus urophylla hybrid clone.

In this way, the highest frequencies are in the fifth class with an average point of $47 \mathrm{~cm}$ in diameter, considering the interventions carried out by the management practices which contributed to the development of the trees left until the clear-cutting operation due to the decrease of competition among them. From the sixth class on, there is a decrease in the number of trees with larger diameters, indicating the stagnation of the forest growth.

According to Figure 1, the number of logs obtained in the performed scenario (S2) showed wood losses in two of the five evaluated assortments. This indicates that the stump and pre-bucking disc surpluses are affecting the distribution of the assortments along the stem, which is the opposite of the company's specifications. In this sense, the increased losses in the higher value-added assortments (LP04), including knot-free logs, present nonconformance problems and represent reductions in production and revenue.

Given the above, concerning the higher value-added logs (LP04 and LP06), the scenarios S3 to S6 presented a higher percentage than scenarios S1 and S2 which shows that the implementation of other scenarios would bring higher economic returns because of the representativeness of these assortments in forest production. Confronting the planned (S1) and performed (S2) scenarios, we can say that the thinner and lower volume assortments do not contribute much to the company's economic goals as they have lower commercial values. They contribute to the total timber production expected from the forest, however.

Regarding the results presented in Table 8, the revenue from S1 to S2 decreased by $5.22 \%$. Fiedler et al. (2013) reported that the wood volume loss retained in the strains provides, in monetary terms, values between 14.92 to $21.82 \mathrm{R} \$ \mathrm{ha}^{-1}$ when you consider the quality of the forest harvesting operation in Eucalyptus stands. Pereira et al. (2012) stated that the lack of operation monitoring triggers raw material waste in any forest harvesting system using semi-mechanized operations. The same authors, when assessing the quality of chainsaw logging in Eucaliptus grandis stands found economic losses of approximately $172.53 \mathrm{R} \$ \mathrm{ha}^{-1}$. Serpe et al. (2018) stated economic losses related to the volume retained in the stumps of $30.60 \mathrm{R} \$ \mathrm{ha}^{-1}$ when studying mixed plantings with Pinus elliottii Engelm and Pinus taeda L.

Scenario 6 (stump and pre-bucking heights of 35.0 and $20.0 \mathrm{~cm}$, respectively) shows a reduction in the amount of wood in four of the five assortments when compared to S1 (planned). Stroher et al. (2014), in a study of mechanized forest harvesting with a Harvester in Pinus taeda plantations, identified wastes of approximately $4.57 \mathrm{t} \mathrm{ha}^{-1}$ in stump and pre-bucking disc heights out of the specification. They also found wood wastes of $0,28 \mathrm{t}$ ha $^{-1}$ in Eucalyptus urophylla stumps in the mechanized forest harvesting using a Feller buncher.

One of the relevant causes for the observed losses is the fact that the harvesting module had recently been reformulated by the company, which demanded greater employee training. According to Fiedler et al. (2013), stump height surpluses refer mainly to the operators' training and skills. They also claim that operational errors result in declassification of higher value assortments for classes with lower market value. For Reboleto et al. (2016), an important factor in productivity is the land's slope, that is, the steeper slopes can reduce productivity. In addition to the wood losses that lead to reduced revenues, the occurrence of non-conformities with the quality control specified by the company triggers difficulties in replanting.

Still regarding the non-conformities of these interventions, any of the quantified scenarios would bring higher revenues than the performed scenario (S2), especially the scenario S3 (stump and pre-bucking disc heights of 10 and $5 \mathrm{~cm}$, respectively) which presented a lower total amount of wood but higher revenues than the scenario S1 (desired). This fact can be explained by the number of LP06 assortments, which have higher commercial value, highlighting the need to optimize the production to obtain larger assortments.

Given the above, the identification of improvement opportunities that prioritize the minimization or eradication of wastes in mechanized forest harvesting operations enables companies to obtain information that can be used in the decision-making process. Also, the pursuit of high-quality production processes through better development and greater use of raw materials enhances the production process and the qualification of workers' labor, mitigating production costs.

\section{CONCLUSIONS}

The results obtained in this study showed that: 
- The forest company operates below the planned scenario (S1), which leads to wood losses and, therefore, reduced revenues. Besides, any of the other scenarios would bring higher economic returns than the scenario $\mathrm{C} 2$. Thus, the implementation of scenarios C3 and C4 in the next activities may bring higher yields of the stands.

- In this sense, the non-conformities in the stands show that the operators of the harvesting machines should be better oriented to reduce wood wastes and facilitate operations in a new rotation. Also, a cut closer to the ground would result in savings in stump lowering operations, which would represent better yield and lower costs. However, these situations should be evaluated considering the damage that may occur in forest machines.

\section{ACKNOWLEDGMENTS}

We thank the company Florestal Gateados LTDA and the Foundation for Research Support of Santa Catarina (FAPESC).

\section{REFERENCES}

BINOTI, D. H. B.; LEITE, H. G.; NOGUEIRA, G. S.; SILVA, M. L. M.; GARCIA, S. L. R.; CRUZ, J. P. Uso da função Weibull de três parâmetros em um modelo de distribuição diamétrica para plantios de eucalipto submetidos a desbaste. Árvore Magazine, Viçosa, v. 34, p. 147-156, 2010.

CAMPOS, B. P. F; BINOTI, D. H. B.; SILVA, M. L.; LEITE, H. G.; BINOTI, M. S. Conversão de árvores em multiprodutos da madeira utilizando programação inteira. Árvore Magazine, Viçosa, v. 37, n. 5, p. 881-887, 2013.

DRAPER, N.R.; SMITH, H. Applied regression analysis. New York: Jonh Willey e Sons. 1966. 407p.

FIEDLER, N. C.; CARMO, F. C. de A.; SÃO TEAGO, G. B.; CAMPOS, A. A. de; SILVA, E. N. da. Análise da qualidade da colheita florestal de eucalipto em diferentes declividades. C.E.F. Magazine, v. 22, n. 1, 2013.

FIGUEIREDO FILHO, A.; RETSLAFF, F.A.S.; KOHLER, S.V.; BECKER, M.; BRANDES, D. Efeito da idade no afilamento e sortimento em povoamentos de Araucaria angustifolia. Floresta e Ambiente Maganize, v. 22, p. 50-59, 2015.

FONWEBAN, J.; GARDINER, B.; MACDONALD, E.; AUTY, D. Taper functions for Scots pine (Pinus sylvestris, L.) and Sitka spruce (Picea sitchensis (Bong.) Carr.). Northern Britain. Forestry. v. 84, p. 49-60, 2011.

INDÚSTRIA BRASILEIRA DE ÁRVORES. IBA Report 2016. Available from: < http://iba.org/images/shared/Biblioteca/IBA_RelatorioAnual2016_.pdf >. Acessed on: 20 June 2017.

KOHLER, S.V.; KOEHLER, H.S.; FIGUEIREDO FILHO, A. Modelos de afilamento para Pinus taeda por classes de idade. Floresta e Ambiente Magazine, p. 470-479, 2013.

MACHADO, C. C.; SILVA, E. N.; PEREIRA, R. S. O setor florestal brasileiro e a colheita florestal. In: MACHADO, C.C. (Ed.). Colheita florestal. 2 ed. Viçosa, MG: UFV, p. 15-42, 2008.

MIGUEL, E.P.; MACHADO, S. do A.; FIGUEIREDO FILHO, A.; ARCE, J.E.; Modelos polinomiais para representar o perfil e o volume do fuste de Eucalyptus urophylla na região norte do Estado de Goiás. Floresta Magazine, Curitiba, PR, v. 41, n. 2, p. 355-368, 2011.

PEREIRA, D. P.; FIEDLER, N. C.; GUIMARÃES, P. P.; MÔRA, R.; Bolzan, H. M. R.; PLASTER, O. B.; Avaliação da qualidade do corte florestal com motosserra. Cerne Magazine, Lavras, v. 18, n. 2, p. 197-203, abr./jun. 2012.

REBOLETO, I.; FIEDLER, N. C.; BERUDE, L. C.; JUVANHOL, R. S.; CANZIAN, W. P. CARMO, F. C. A. de. Análise da qualidade do corte semimecanizado de eucalipto em diferentes declividades. Revista Agropecuária Científica no Semiárido, v. 12, n. 3, p. 268-272, 2016.

SCHÖEPFER, W. Automatisierung des Massem, Sorten und Wertberechnung stenender Waldbestande Schriftenreihe Bad. [S.I]: Wurtt-Forstl. 1966.

SERPE, E. L.; FIGUEIREDO, A. F.; ARCE, J. E. Perdas volumétricas relativas à colheita florestal e seus reflexos econômicos. BIOFIX Scientific Journal, v. 3, n. 1, p. 172-176, 2018.

FLORESTA, Curitiba, PR, v. 50, n. 1, p. 1133 - 1142, jan/mar 2020.

Oliveira, G. S. et.al.

ISSN eletrônico 1982-4688

DOI: $10.5380 /$ rf.v50 i1.61775 
SOUZA, C. A. M. de; CHASSOT, T.; FINGER, C. A. G.; SCHNEIDER, P. R.; FLEIG, F. D. Modelos de afilamento para o sortimento de fuste de Pinus taeda L. Ciência Rural, Santa Maria, v. 38, n. 9, p. 2506-2511, 2008.

STROHER, R. R.; NIKKEL, A.; NODARI, A. N.; SANTOS, A. S.; ROBERT, R. C. G. Avaliação da perda de madeira em dois sistemas de colheita florestal mecanizada. Biosfera Encyclopedia, Goiânia, v. 10, n .19, p. 238249, 2014.

TRINDADE, C.; JACOVINE, L. A. G.; REZENDE, J. L. P.; SARTÓRIO, M. L. Gestão e controle da qualidade na atividade florestal. Viçosa-MG: Editora UFV, 2012. 253 p.

TÉO, S. J.; ROCHA, S. P. da.; BORTONCELLO, A. C.; PAZ, R. A. COSTA, R. H. da. Dinâmica da distribuição diametrica de povoamentos de Pinus taeda, na região de Caçador, SC. Brazilian Journal of forestry research, Colombo - PR, v. 31, n. 67, p. 183-192, jul/set. 2011.

YOSHITANI JUNIOR, M.; NAKAJIMA, N. Y.; ARCE, J. E.; MACHADO, S. A.; DRUSZCZ, J. P.; HOSOKAWA, R. T.; MELLO, A. A. Funções de afilamento para plantios desbastados de Pinus taeda L. Floresta Magazine, Curitiba - PR, v. 42, n. 1, p. 169-176, jan/mar. 2012. 